\title{
Allergen Immunotherapy in Allergic Respiratory Diseases
}

\section{From Mechanisms to Meta-analyses}

\author{
Ravi K. Viswanathan, MD; and William W. Busse, MD
}

\begin{abstract}
Allergen-specific immunotherapy (SIT) involves the repeated administration of allergenic extracts to atopic individuals over a period of 3 to 5 years either subcutaneously (SCIT) or sublingually (SLIT) for the treatment of allergic respiratory diseases, including asthma and allergic rhinitis (AR). In studies, SCIT and SLIT have been shown to improve existing symptoms of asthma and AR and to also have the capability to cause disease-modifying changes of the underlying atopic condition so as to prevent new allergic sensitization as well as arrest progression of AR to asthma. Recent evidence suggests that immunotherapy brings about these effects through actions that use T-regulatory cells and blocking antibodies such as $\operatorname{IgG}_{4}$ and $\operatorname{IgA} A_{2}$, which can then result in an "immune deviation" from a T-helper (Th) 2 cell pattern to a Thl cell pattern. Numerous meta-analyses and studies have been performed to evaluate the existing data among these studies, with the consensus recommendation favoring the use of immunotherapy because of its potential to modify existing diseases. Significant adverse reactions can occur with immunotherapy, including anaphylaxis and, very rarely, death. A primary factor in considering SIT is its potential to provide longlasting effects that are able to be sustained well after its discontinuation. Given the significant burden these allergic diseases impose on the health-care system, SIT appears to be a cost-effective adjunctive treatment in modifying the existing disease state.

CHEST 2012; 141(5):1303-1314
\end{abstract}

Abbreviations: $\mathrm{AR}=$ allergic rhinitis; $\mathrm{BHR}=$ bronchial hyperresponsiveness; $\mathrm{PEF}=$ peak expiratory flow; $\mathrm{SCIT}=$ subcutaneous immunotherapy; SIT = allergen-specific immunotherapy; SLIT = sublingual immunotherapy; SMD = standardized mean difference; $\mathrm{TGF}=$ transforming growth factor; $\mathrm{Th}=\mathrm{T}$ helper; $\mathrm{Treg}=\mathrm{T}$ regulatory

O ver the past 2 decades, the prevalence of allergic respiratory diseases has increased, in part reflecting changes in lifestyle and environment that promote a T-helper (Th) 2 cell phenotype. ${ }^{1}$ It has been estimated that up to $20 \%$ of the US and Western Europe populations may be afflicted by allergic respiratory diseases. ${ }^{2,3} \mathrm{~A}$ recent estimate of the total national

Manuscript received November 2, 2011; revision accepted December 30, 2011.

Affiliations: From the Division of Allergy, Pulmonary, and Critical Care, Department of Medicine, University of Wisconsin School of Medicine and Public Health, Madison, WI.

Correspondence to: William W. Busse, MD, Division of Allergy, Pulmonary, and Critical Care, Department of Medicine, University of Wisconsin School of Medicine and Public Health, K4/910 CSC, 600 Highland Ave, Madison, WI 53792; e-mail: wwb@medicine. wisc.edu

(C) 2012 American College of Chest Physicians. Reproduction of this article is prohibited without written permission from the American College of Chest Physicians (http://www.chestpubs.org/ site/misc/reprints.xhtml).

DOI: 10.1378/chest.11-2800 medical expenditure attributable to adult asthma was reported as $\$ 18$ billion, with the largest contributors being prescription drugs and inpatient hospitalizations. ${ }^{4,5}$ Although allergen avoidance is an integral component and step of therapy, it is often impractical and insufficient. As a consequence, the mainstay of allergic disease management has been pharmacotherapy, especially antihistamines, bronchodilators, and inhaled/intranasal corticosteroids, which are targeted to regulate inflammation of the upper and lower airways. Although these treatments are effective and, in most cases, safe, they offer no lasting benefit once treatment is stopped and have limited intrinsic disease-modifying effects. Moreover, it has become apparent that allergic diseases are the result of immune dysregulation and reflect an impairment in the natural tolerance that develops to allergens. ${ }^{6,7}$

Immunotherapy has the potential to modify fundamental, underlying disease mechanisms and to have, 
in some patients, a sustained effect. This aspect of therapy is especially appealing and of interest. Initially described by Noon ${ }^{8}$ and Freeman ${ }^{9}$ a century ago, allergen-specific immunotherapy (SIT) involves the repeated administration of allergenic extracts to atopic individuals with the goal of inducing clinical and immunologic tolerance. Although the basic premise of SIT has remained the same, advances have been made in the elucidation of the mechanisms of SIT, with particular emphasis on T-cell immunology and a more recent focus on $\mathrm{T}$ regulatory (Treg) cells and antibody isotypes. ${ }^{6,10}$

Historically, SIT has been administered using a subcutaneous injection route (subcutaneous immunotherapy [SCIT]); but there are increasing data to support the use of a sublingual route (sublingual immunotherapy [SLIT]), which, because of its site of administration, may have effects primarily on the respiratory system. Importantly, SIT has been shown to have disease-modifying properties that can alter the natural course of the allergic disease, particularly asthma and allergic rhinitis (AR), and provide lasting benefit that is sustained when the treatment is completed. Thus, immunotherapy has the potential to mitigate the risk of new allergic sensitizations, improve current symptoms of AR/asthma and lung function parameters, decrease the need for medication use, and prevent progression of upper airway allergic disease to asthma. ${ }^{11,12}$

Traditionally, SIT is administered by giving incrementally increasing doses of an allergen over an 8- to 16-week build-up phase followed by 3 to 5 years of a monthly maintenance dose. ${ }^{13}$ It is necessary to bear in mind that there is considerable heterogeneity in the preparation and administration of allergenic extracts as well as the level of clinical efficacy of individual and multiallergen extracts. Meta-analyses and studies on SIT for asthma and AR have to contend with these variabilities, which limits recommendations that can be drawn among various allergens and asthma outcomes. Although SIT may be beneficial in broad clinical terms, there are also risks associated with its use, including anaphylaxis, which, fortunately, only rarely results in a death. Thus, it is an absolute requisite for the prescribing physician to carefully weigh the benefits against risks for each individual patient prior to initiating SIT. In our review, we will first highlight the mechanisms of allergic reactions and SIT and then discuss the effectiveness of SIT in allergic respiratory diseases, particularly asthma and AR.

\section{Mechanisms of Allergic Reactions AND ALLERGEN-SPECIFIC IMMUNOTHERAPY}

To more fully appreciate and understand the mechanisms of SIT, it is important to first review aspects of allergic reactions, including early- and late-phase responses, the latter of which has served as a model for allergic inflammation. The initial component of the allergic reaction is sensitization, which involves the differentiation and clonal expansion of allergenspecific Th2 cells, which, in turn, stimulate production of IL-4 and IL-13 to induce an antibody class switch to $\operatorname{IgE}$ and production of allergen-specific IgE antibodies. These allergen-specific IgE molecules attach to cells, such as mast cells and basophilic leukocytes, to complete the sensitization process. When an allergen is re-encountered, cross-linking of allergen-specific IgE bound to FceR1 on mast cell surface occurs to trigger the release of vasoactive amines, leukotrienes, prostaglandins, and other chemokines and with this activation initiate the early or immediate response. Four to 6 hours later, a late-phase reaction may occur as a consequence of ongoing generation of mast cell mediators and the activation of allergen-specific Th2 cells to generate a variety of cytokines (IL-4, $-5,-9,-13$ ), which have a wide range of effects, including smooth muscle cell activation, increased endothelial cell adhesion and basophil transmigration, and recruitment of eosinophils to further the development of an inflammatory milieu. ${ }^{6,10}$ Additionally, a Th2 cell activationinduced apoptosis of interferon- $\boldsymbol{\gamma}$-producing Th1 cells further shifts the balance toward a Th2 cell profile. ${ }^{14}$ This exaggerated and dysregulated Th2 cell pattern of response underlies the pathophysiology of many atopic diseases.

As stated previously, SIT attempts to attenuate this immune dysregulation in allergic reactions by inducing immunologic and clinical tolerance. SIT has been shown to suppress both the early- and late-phase allergic responses in the skin, nose, and lung. ${ }^{15,16}$ Modification of the allergic response has been demonstrated with SIT for grass pollen, cat allergen, birch pollen, and mite allergen sensitization..$^{17-19}$ A decreased latephase cellular infiltrate of eosinophils, mast cells, neutrophils, and $\mathrm{T}$ cells has been observed following immunotherapy. ${ }^{20,21}$

A number of mechanisms common to both SCIT and SLIT have been put forth to explain how this is accomplished. With both SCIT and SLIT, allergenspecific IgE rises transiently with initiation of treatment, but IgE then gradually returns to baseline levels during the maintenance phase of therapy. This $\operatorname{IgE}$ effect has been demonstrated with immunotherapy to grass pollen and ragweed allergens. ${ }^{22-24}$ However, this decline in allergen-specific IgE does not temporally correlate with clinical improvement or the blunted cutaneous response to the allergen that is observed in the initiation phase of SIT, and, therefore, it is unlikely to be the dominant mechanism by which immunotherapy leads to benefit. 
It was also observed that both SCIT and SLIT induce production of allergen-specific IgG antibodies, especially $\operatorname{IgG}_{4}$ and $\operatorname{IgG}_{1}$, which disrupt the interaction between the allergen and mast cell-bound $\operatorname{IgE}$ by directly competing for the same epitope. This "blocking" effect is not only the result of an increase in the quantity of $\mathrm{IgG}_{4}$ antibodies but also because SIT amplifies the inhibitory effect of $\mathrm{IgG}_{4}$ on IgE-mediated responses in a qualitative manner. ${ }^{6,25,26}$ However, controversy still looms around this issue, as some studies of SIT have found a clear correlation with an increase in $\operatorname{IgG}_{4}$ levels to clinical improvement, whereas others have not. ${ }^{27-29}$ Also worth noting is the induction of $\mathrm{IgA}_{2}$ antibodies with SIT, which results in $\mathrm{IgG}_{4}$ production through an IL-10-mediated mechanism. ${ }^{30}$

Perhaps a more important mechanism of benefit with SCIT and SLIT is the appearance and activity of $\mathrm{FOXP}^{+}{ }^{+} \mathrm{CD} 25^{+}$Treg cells to produce IL-10 and transforming growth factor (TGF)- $\beta$ to suppress activity of allergen-specific Th2 cells with the subse- quent recruitment of other inflammatory effector cells. Additionally, the production of IL-10 and TGF- $\beta$ from Treg cells stimulates B cells to undergo class switching and produce the protective antibodies $\mathrm{IgG}_{4}$ and $\operatorname{IgA} A_{2} .31,32$

Dendritic cells and oral mucosal Langerhans cells also play a role in the induction of tolerance, whereby they stimulate production of Treg subsets and are also able to directly secrete the key effector cytokines, IL-10 and TGF- $\beta$, when subjected to an allergen challenge. ${ }^{33}$ Increases in IL-12, a potent Th1 cell cytokine, have also been observed with SIT and help counteract this Th2 cell-dominant inflammatory profile. ${ }^{34}$ Overall, these events result in an immune deviation from a Th2 cell pattern of response to more of a Th1 and Treg cell pattern and induce peripheral T-cell tolerance to allergens, which correlates with clinical improvement in allergic inflammation. ${ }^{35}$ An illustration of the potential mechanisms is depicted in Figure 1.

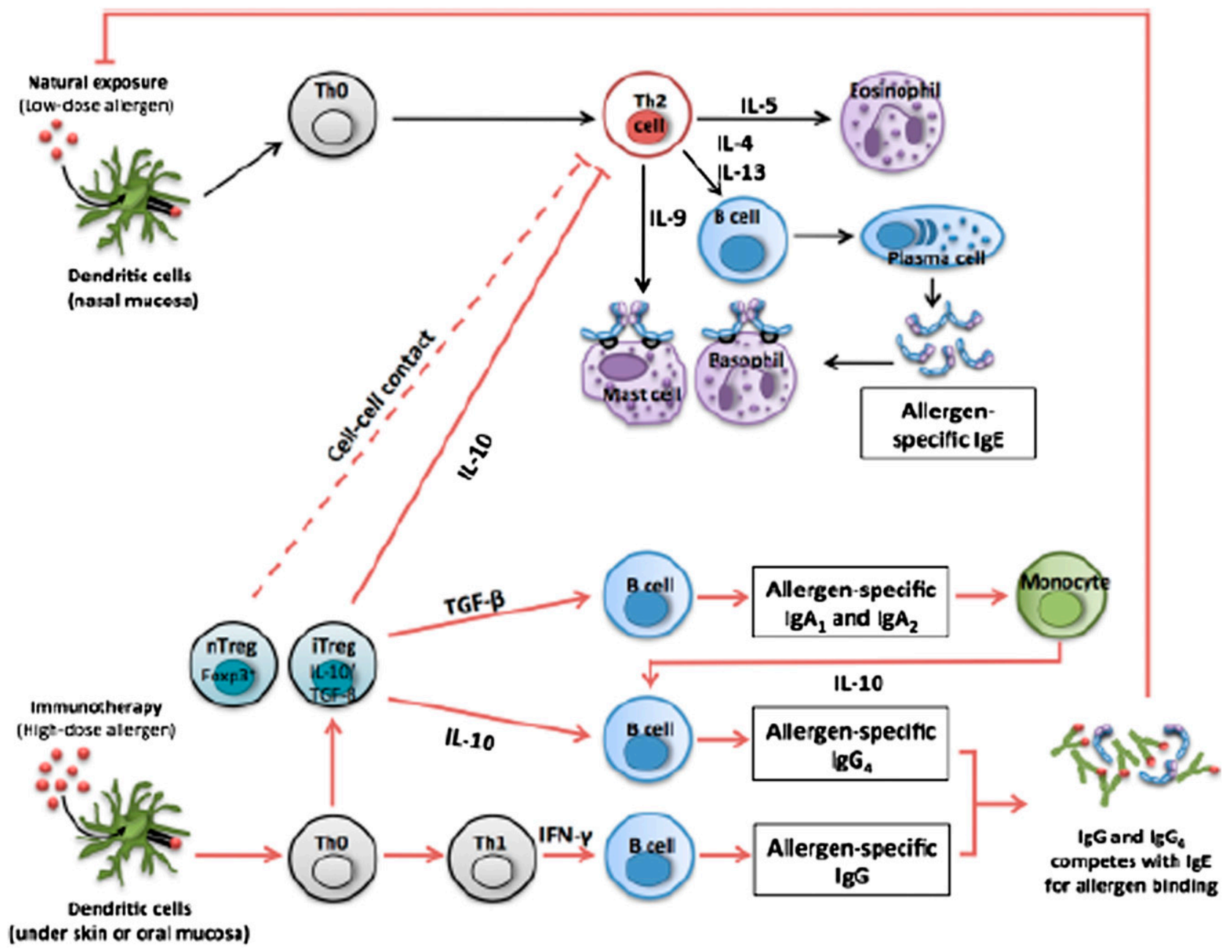

FIGURE 1. Immunologic mechanisms of immunotherapy. IFN = interferon; TGF = transforming growth factor; Th $=$ T-helper cell; Treg $=$ T-regulatory cell. (Reproduced with permission from Shamji and Durham. ${ }^{25}$ ) 


\section{ALLERGEN IMMUNOTHERAPY IN ASTHMA}

Allergen exposure in the sensitized patient is an important factor resulting in loss of asthma control in both adult and pediatric populations. Although current asthma therapeutics, particularly inhaled corticosteroids and bronchodilators, have been effective in mitigating the frequency of asthma exacerbations and a loss of disease control, they are ineffective or insufficient in some patients. Allergen immunotherapy has been shown to be beneficial for many patients and is frequently added to existing treatment of allergic asthma in the United States and in many parts of Europe. Indications and contraindications for initiation or continuation of immunotherapy are summarized in Tables 1 and 2. Recently published practice parameters indicate that allergen immunotherapy is an effective treatment of allergic asthma (strength of recommendation: A). ${ }^{36}$ Data on which this conclusion is based are reviewed here and summarized in Tables 3 and 4.

\section{The Effect of SCIT in Asthma}

Many studies have assessed the efficacy of SCIT in asthma over the past 50 years. A recently published Cochrane review meta-analysis of SCIT assessed 88 studies on 3,459 subjects with asthma and included 42 trials for dust mites, 27 for pollen, 10 for animal dander, two for molds, two for latex, and six for multiple allergens. Given the intrinsic nature of such studies and this expanded time frame, there was significant heterogeneity among the various com-

\section{Table 1-Indications for Specific Immunotherapy}

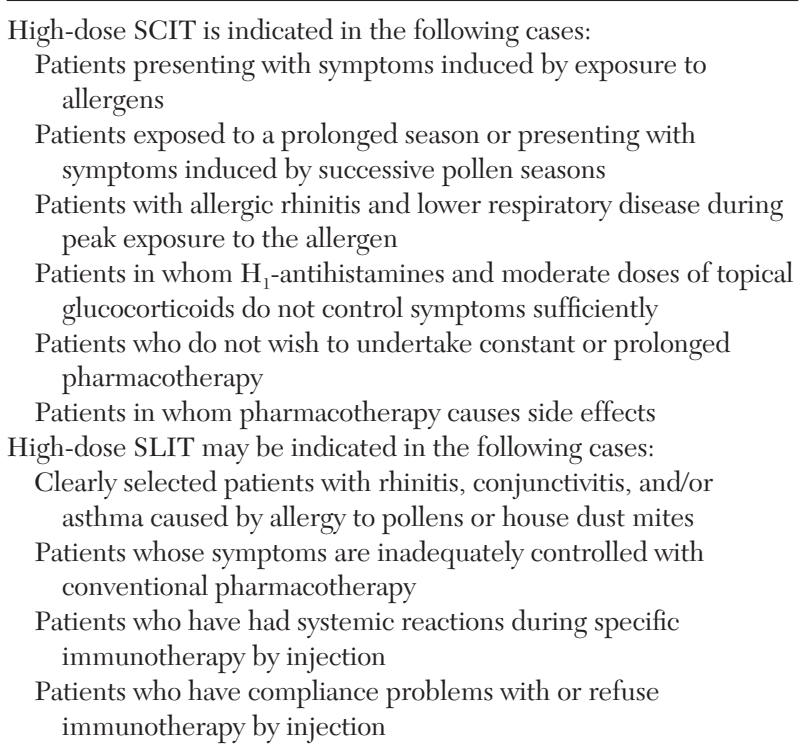

$\overline{\text { SCIT }}=$ subcutaneous immunotherapy; SLIT $=$ sublingual immunotherapy. (Reproduced with permission from Calderón et al. ${ }^{7}$ )
Table 2-Contraindications to Immunotherapy

Unstable or uncontrolled asthma

Pregnancy (maintenance injections may be continued during pregnancy)

Use of $\beta$-blockers

Concurrent presence of immunodeficiency or autoimmune disease or malignancy

Lack of adequate resuscitation equipment and/or personnel

Young children $(<5 \mathrm{y})$

Inability to comply with established immunotherapy protocols

parisons between the studies, and only 16 trials had clear evidence of allocation concealment. Overall, SIT improved asthma symptoms (standardized mean difference [SMD], $-0.59 ; 95 \% \mathrm{CI},-0.83$ to -0.35$)$, reduced medication use $(\mathrm{SMD},-0.53 ; 95 \% \mathrm{CI},-0.80$ to -0.27 ), and diminished bronchial hyperresponsiveness (BHR) (SMD, -0.35 ; 95\% CI, -0.59 to -0.11 ). Statistically, the meta-analysis found that it would require treating three subjects to prevent an exacerbation for one individual, four subjects to improve medication use in one, and four subjects to avoid nonspecific or allergen-specific BHR in one patient, respectively. In general, it was noted that symptom scores were improved more significantly by mite and pollen immunotherapy, whereas allergen-specific BHR was improved by mite, pollen, and animal dander immunotherapy. ${ }^{37}$ Lung function parameters, however, were not reported in all studies, and improvements in $\mathrm{FEV}_{1}$ or peak expiratory flow (PEF) were not consistently demonstrated by use of SCIT, though a nonsignificant trend toward improvement was observed. Given these variable results, the conclusions from this meta-analysis deserve cautious interpretation and acceptance, as we need to consider many variables, including the allergen used, the outcome assessed, and the characteristics of the patients enrolled.

Another meta-analysis ${ }^{47}$ of 24 prospective studies in allergic asthma showed that SCIT, compared with placebo, improved asthma symptoms (OR, 2.76; 95\% CI, 2.22-3.42), lung function measures (OR, 2.87; 95\% CI, 1.82-4.52), medication use (OR, 2.00; 95\% CI, 1.46-2.72), and protection against bronchial challenge (OR, 1.81; 95\% CI, 1.32-2.49). More recently, a 2-year treatment study of birch pollen immunotherapy demonstrated improvement in clinical indices of asthma. ${ }^{48}$ Three other immunotherapy studies of dust mite in adult and pediatric subjects with asthma also demonstrated improvements in symptom scores, medication use, and BHR. ${ }^{49-51}$ Similarly, studies for grass pollen immunotherapy ${ }^{52}$ showed improvement in asthma symptom scores, whereas ragweed immunotherapy resulted in improved asthma symptoms and peak flow rates during the pollen season. ${ }^{33}$

In contrast, a double-blind study on 121 allergic children with moderate to severe perennial asthma, 
who were given mixed-allergen SCIT of up to seven aeroallergens, failed to show any significant difference in medication scores, symptom scores, PEF, and median methacholine provocation concentration producing $20 \%$ decline in $\mathrm{FEV}_{1}$ when compared with placebo. ${ }^{54}$ Several other studies of SCIT, particularly with mites, failed to demonstrate a significant benefit or noted only marginal benefit for asthma in terms of medication or symptom scores for both adults and children. ${ }^{55,56}$ In light of this information, the debate continues among clinicians as to whether and under what conditions to prescribe SCIT for asthma. One inherent problem with many of these studies is the need to maintain optimal asthma control during the clinical trial. Under such circumstances, there is little room to achieve or perceive benefit.

It is important to note that SIT may not only improve symptoms in asthma but also that this approach may have the ability to alter the natural march of atopic disease and prevent progression to asthma. An analysis by Jacobsen et al, ${ }^{57}$ as a follow-up to the Preventive Allergy Treatment study on children with birch or grass pollen allergy who had been treated with SCIT for 3 years, revealed that immunotherapy provided long-term clinical benefit and prevented the development (OR, 0.22) of asthma for up to 7 years after discontinuing it (Fig 2). ${ }^{57}$ Polosa et al, ${ }^{58}$ in a retrospective study on adults with AR treated with SCIT for 3 to 5 years, concluded that treatment with immunotherapy significantly reduced (OR, 0.53; 95\% CI, 0.32-0.86) the development of new-onset asthma.

\section{The EfFect of SLIT in Asthma}

There has been considerable interest that the administration of allergen via a mucosal route (ie, po) may also be effective and improve safety, as allergens are not given systemically. In the past 25 years, sublingual immunotherapy has emerged as a viable

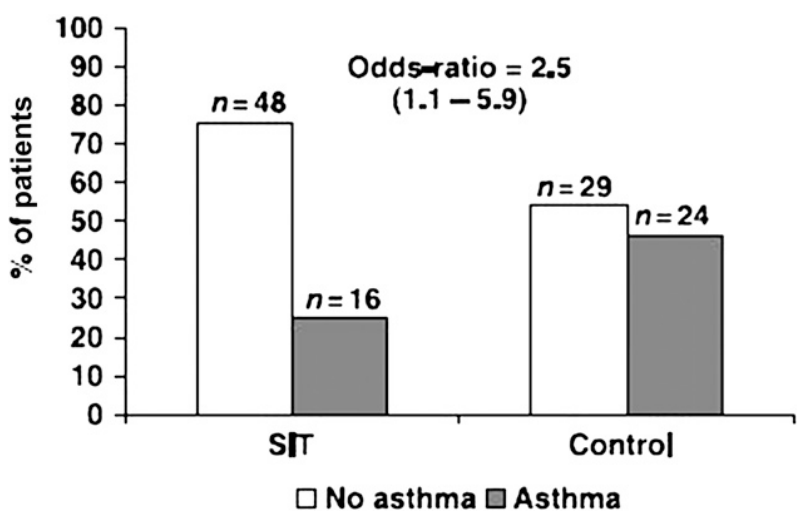

FIGURE 2. Development of asthma 7 years following specific immunotherapy. (Reproduced with permission from Jacobsen et al. ${ }^{57}$ ) and efficacious alternative to SCIT and with an increased margin of safety. Although not currently used in the United States, SLIT has been extensively tested in clinical trials in the United States and Europe, where it appears to carry only a fraction of the risk of SCIT for serious adverse events. SLIT extracts can be administered in the form of soluble tablets or drops (administered sublingually) and standardized using biologic and immunologic methods. For SCIT, the effective doses of extract that produce the beneficial effect have been defined, but with SLIT the studies vary greatly in areas of dose, frequency, and duration, making a consensus on treatment difficult at present. Multiple meta-analyses have evaluated the efficacy of SLIT in asthma. An important caveat to bear in mind is that many of the studies included in these meta-analyses were underpowered and not always specifically designed to evaluate efficacy in asthma. Consequently, it is likely premature to conclude on the effectiveness of SLIT in asthma.

With those reservations in mind, Calamita et al ${ }^{38}$ performed a meta-analysis on the efficacy of SLIT in asthma that included 25 studies on 1,706 adults and children, of which eight studies were for mites, 14 studies for pollen, one study for latex, and two for mixed allergens. Significant improvement in symptoms (relative risk $=0.48 ; 95 \%$ CI, 0.40-0.57) were noted in seven studies, with a reported number needed to treat of 3.7 in order to avoid exacerbation in one. Significant improvements in $\mathrm{FEV}_{1}$ and forced expiratory flow, midexpiratory phase (SMD 1.48 and 1.06, respectively) were noted in four studies. However, when analyzing asthma symptoms and medication use as continuous outcomes, the reductions were not significant (SMD, -0.38 and -0.91 ). Overall, the authors concluded that SLIT improved asthma outcomes but, perhaps, to a lesser extent than with SCIT.

Another meta-analysis of SLIT in asthma included nine studies on 441 children, aged 3 to 18 years, of which six were for dust mites and three for pollen. A significant reduction in symptom score (SMD, -1.14; $95 \% \mathrm{CI},-2.10$ to -0.18$)$ and medication score (SMD, $-1.63 ; 95 \% \mathrm{CI},-2.83$ to -0.44 ) was noted with SLIT compared with placebo. In subgroup analyses, the noted improvement was more pronounced with house dust mites than pollen. ${ }^{39}$

A more focused meta-analysis ${ }^{41}$ of nine studies in 452 adults and children with house dust mite SLIT for asthma showed significant improvement in symptom scores $(\mathrm{SMD},-0.95 ; 95 \% \mathrm{CI},-1.74$ to -0.15 ) and medication scores (SMD, $-1.48 ; 95 \% \mathrm{CI},-2.70$ to -0.26). An additional meta-analysis of seven studies in 256 children revealed statistically significant reductions in asthma symptom scores (SMD, -1.42; $95 \% \mathrm{CI},-2.51$ to -0.34$)$ and medication requirement scores (SMD, -1.01); the authors concluded that 
Table 3-Meta-analyses of Randomized Controlled Trials of SIT for Treating Allergic Asthma

\begin{tabular}{|c|c|c|c|c|c|}
\hline Study/Year & Patients & Allergens & $\begin{array}{l}\text { Symptom Scores, } \\
\text { SMD }(95 \% \text { CI })\end{array}$ & $\begin{array}{l}\text { Medication Scores, } \\
\text { SMD }(95 \% \mathrm{CI})\end{array}$ & Comment \\
\hline Abramson et al ${ }^{37} / 2010$ & $\begin{array}{l}\text { 3,459 children } \\
\text { and adults }\end{array}$ & $\begin{array}{l}\text { SCIT } \\
\text { Seasonal or } \\
\text { perennial }\end{array}$ & $\begin{array}{c}-0.59(-0.83,-0.35) \\
\mathrm{I}^{2}=90 \%\end{array}$ & $\begin{array}{c}-0.53(-0.80,-0.27) \\
\mathrm{I}^{2}=67 \%\end{array}$ & $\begin{array}{l}\text { Open trials included } \\
\text { No detailed evaluation of safety } \\
\text { Considerable heterogeneity }\end{array}$ \\
\hline Calamita et al ${ }^{38 / 2006}$ & $\begin{array}{l}\text { 1,706 adults } \\
\text { and children }\end{array}$ & $\begin{array}{l}\text { SLIT } \\
\text { Seasonal and } \\
\text { perennial }\end{array}$ & $\begin{array}{c}-0.38(-0.79,-0.03) \\
\mathrm{I}^{2}=64 \%\end{array}$ & $\begin{array}{c}-0.91(-1.94,0.12) \\
\mathrm{I}^{2}=92 \%\end{array}$ & $\begin{array}{l}\text { Considerable heterogeneity } \\
\text { Weak methodology } \\
\text { Open trials included }\end{array}$ \\
\hline Penagos et al ${ }^{39 / 2008}$ & 441 children & $\begin{array}{l}\text { SLIT } \\
\text { Seasonal and } \\
\text { perennial }\end{array}$ & $\begin{array}{c}-1.14(-2.10,-0.18) \\
\mathrm{I}^{2}=94 \%\end{array}$ & $\begin{array}{c}-1.63(-2.83,-0.44) \\
\mathrm{I}^{2}=95 \%\end{array}$ & Considerable heterogeneity \\
\hline $\begin{array}{l}\text { Olaguíbel and Alvarez } \\
\text { Puebla }{ }^{40} / 2005\end{array}$ & 256 children & $\begin{array}{l}\text { SLIT } \\
\text { Seasonal and } \\
\text { perennial }\end{array}$ & $\begin{array}{l}-1.42(-2.51,-0.34) \\
\mathrm{I}^{2}=\text { Not reported }\end{array}$ & Not reported & $\begin{array}{l}\text { Small numbers } \\
\text { Heterogeneity not reported }\end{array}$ \\
\hline Compalati et al ${ }^{41 / 2009}$ & $\begin{array}{l}452 \text { adults } \\
\text { and children }\end{array}$ & $\begin{array}{l}\text { SLIT } \\
\text { House dust mite }\end{array}$ & $\begin{array}{c}-0.95(-1.74,-0.15) \\
\mathrm{I}^{2}=93 \%\end{array}$ & $\begin{array}{c}-1.48(-2.70,-0.26) \\
\mathrm{I}^{2}=96 \%\end{array}$ & $\begin{array}{l}\text { Considerable heterogeneity } \\
\text { despite focus on a single allergen }\end{array}$ \\
\hline
\end{tabular}

SIT $=$ allergen-specific immunotherapy. See Table 1 legend for expansion of other abbreviations. (Reproduced with permission from Calderón et al. ${ }^{42}$ )

sublingual immunotherapy is safe and effective to abrogate respiratory allergies (Table 3).40,42 Another study examined the effectiveness of SLIT with cat extracts on 50 cat-allergic patients with or without asthma. After a year of treatment, asthma symptoms and PEF improved significantly in the active treatment group compared with nonsignificant changes with placebo when placed in a "cat room" to simulate natural exposure. Although a cat room exposure might not necessarily mimic a natural exposure, this study illustrated that SLIT can also be an effective option for animal allergy. 59

Several studies of SLIT for grass and mites have failed to show any or demonstrate only marginal benefit for asthma on asthma symptom scores, medication scores, or lung function parameters, including $\mathrm{FEV}_{1}$ or PEF. In at least two of these studies, most of the patients had minimal to no asthma symptoms at baseline and throughout the trial, likely precluding the detection of a beneficial effect of SLIT. ${ }^{60,61}$

As with SCIT, numerous studies document that SLIT may also modify the natural history of allergic disease and prevent the inception of asthma. A pediatric AR study used coseasonal grass pollen SLIT treatment of 3 years and revealed that the subsequent development of asthma was 3.8 times more likely in the control group than the treated group. ${ }^{62}$ In another study of 216 children with AR with or without intermittent asthma, patients were randomized to medications only or medications plus SLIT for 3 years. A decrease in the incidence of mild persistent asthma (OR, 0.04; 95\% CI, 0.01-0.17) was found in the SLIT arm along with a dramatic decline in the prevalence of a positive methacholine challenge. ${ }^{63}$

Overall, the data from various studies and metaanalyses of SCIT and SLIT on asthma strike a note of cautious optimism for immunotherapy. There is, however, significant heterogeneity in existing stud- ies, and many studies were underpowered or not designed to specifically evaluate asthma outcomes, which might dampen the validity of these metaanalyses. Although beneficial outcomes were noted in a number of studies, the degree of these effects was sometimes small and did not always correlate with improved lung function indices. ${ }^{37-39,41,47}$ Despite these limitations, SCIT and SLIT have been shown in a number of studies to have significant diseasemodifying effects on either the progression or development of asthma, an effect not seen with other forms of treatment.

\section{Allergen ImMUNOTHERAPY IN AR}

AR affects roughly 500 million patients worldwide to impose a significant burden on the health-care system at an estimated annual cost of $\$ 11.2$ billion as of $2005 .^{64,65}$ Allergic sensitization, which may first appear as AR, is a dominant risk factor for the development of asthma. It is estimated that SIT is used in only about $2 \%$ to $6 \%$ of the approximate 55 million patients in the United States with allergic diseases. ${ }^{66}$ Although perhaps being underused, allergen immunotherapy is most effective and safe for AR and provides a model system to evaluate the effects and mechanisms of allergen immunotherapy. Moreover, SIT treatment has led to a longer duration of symptom reduction compared with traditional pharmacotherapy. As in asthma, a myriad of meta-analyses and studies have been performed and replicated to illustrate the efficacy and safety of SIT in AR.

\section{The EFFECT OF SCIT FOR AR}

A Cochrane review of SCIT in seasonal AR included 51 studies on 2,871 adults and children, of which 
16 trials were for mixed grass, 12 for ragweed, five for timothy grass, six for Parietaria, four for birch, three for cedar, one each for Juniperus ashei, Cocos, and Bermuda grass. Symptom score data from 15 studies showed a significant reduction in the SCIT group (SMD, $-0.73 ; 95 \% \mathrm{CI},-0.97$ to -0.50 ), and medication scores from 13 studies revealed a significant reduction in the immunotherapy-treated group (SMD, $-0.57 ; 95 \% \mathrm{CI},-0.82$ to -0.33 ). Additionally, specific nasal, bronchial, and ocular symptom scores and quality-of-life scores were also tabulated for various subsets of these studies, with all of the indices favoring the immunotherapy-treated groups. ${ }^{43}$ An independent review of SCIT studies performed in the past decade for AR confirmed these findings and additionally concluded that SCIT was specifically efficacious to ameliorate symptoms and reduce rescue medication use when treated with grass, birch, Parietaria, mite, and ragweed immunotherapy. ${ }^{67}$

Another study demonstrated the efficacy and safety of SCIT in treatment-refractory patients with seasonal AR caused by grass pollen. ${ }^{68}$ Quality-of-life outcomes specifically and significantly improved in multiple studies of grass pollen SCIT with seasonal $\mathrm{AR},{ }^{69}$ whereas a dose-dependent effect of improved symptoms when placed on a higher maintenance dose was noted in another study of grass pollen SCIT. ${ }^{70}$ When treated for 3 years, long-term benefit, which ranged from 3 to 12 years, was also demonstrated for SCIT in seasonal AR in multiple studies, including grass pollen, birch pollen, and ragweed. ${ }^{57,71,72}$

In contrast, efficacy data for SCIT in perennial AR is less robust given the difficulty in discerning what allergens, or factors, contribute to symptoms and to what degree. A study of dust mite SCIT in perennial AR showed statistically significant $(P<.01)$ improvement in rhinitis symptoms, rescue medication, and visual analog scores along with reductions in responses to nasal challenge and SPT. ${ }^{73}$ Similarly, SCIT with animal dander demonstrated, in cat-allergic patients with perennial rhinoconjunctivitis, improved symptom scores and reduced responses to conjunctival provocation as well as decreases in skin test responses. ${ }^{74}$

Like asthma, SCIT for AR also led to diseasemodifying effects as illustrated by preventing new sensitizations. A study on children with asthma with dust mite sensitization showed that at 3 years of treatment, new sensitizations appeared in only $50 \%$ of children treated with SCIT compared with $100 \%$ of those in the control group. ${ }^{75}$ Similar decreases in the incidence of new sensitizations were noted at even longer follow-up periods (5-6 years) in children and adults treated with SCIT compared with placebo. ${ }^{76,77}$ An interesting analysis by Matricardi et al ${ }^{78}$ compared SCIT to pharmacotherapy based on meta-analyses; the authors concluded that SCIT was as effective as, or better than, pharmacotherapy in controlling rhinitis symptoms even in the first season of treatment.

\section{The EFFECT OF SLIT in AR}

The effectiveness of SLIT in AR has been primarily evaluated by two meta-analyses, with one in the framework of a Cochrane review, which included 60 studies on 4,589 adults and children, of which 49 studies were used for the meta-analysis. Of the 49 studies, 23 were for grass pollen, nine for trees, five for Parietaria, two for ragweed, eight for house dust mite, one for cat, and one for mixed allergens (birch and grass). Overall, SLIT led to a significant reduction in symptoms (SMD, $-0.49 ; 95 \% \mathrm{CI},-0.64$ to -0.34 ) and medication use (SMD, $-0.32 ; 95 \% \mathrm{CI},-0.43$ to -0.21 ). Sophisticated subgroup analyses were also included to reveal greater efficacy for house dust mite (perennial allergens) than other seasonal allergens, including grass. A trend toward a greater reduction in symptom scores was noted with a longer duration ( $>12$ months) of SLIT. ${ }^{4}$

Another meta-analysis, exclusively in the pediatric population, included 10 studies, of which four were for house dust mites, three for grass mixes, one each for Parietaria and olive, and one for pollen mix. Overall, a significant decline in both symptoms (SMD, $0.56 ; 95 \% \mathrm{CI},-1.01$ to -0.10$)$ and rescue medication use (SMD, 0.76 ; $95 \% \mathrm{CI},-1.46$ to -0.06 ) was found. In concordance with the previous meta-analysis, subgroup analyses also found a greater efficacy when SLIT was used for a longer duration ( $>18$ months). Interestingly, and in contrast, subgroup analyses with this meta-analysis suggested that SLIT administered for pollen was more efficacious than for house dust mites (Table 4).45

Long-term clinical efficacy has been reaffirmed by Durham et $\mathrm{al}^{79}$ in a study of SLIT for grass polleninduced allergic rhinoconjunctivitis. Sustained clinical improvement and immunomodulatory changes were noted at 1 year after treatment. ${ }^{79}$ There remains a relative paucity of data for SLIT in animal allergy, although the few available studies with cat extracts have shown potential efficacy. ${ }^{59,80}$ SLIT for AR also has the potential to mitigate the inception of new sensitizations as documented by Marogna et al, ${ }^{63}$ showing an incidence of $3.1 \%$ in the SLIT-treated patients vs $34.8 \%(P=.01)$ in control subjects at a 3-year follow-up.

An important caveat to bear in mind with the various meta-analyses published for SCIT and SLIT is the significant heterogeneity with regard to patient population, allergen extracts used, and disease outcomes measured. The presence of publication bias also introduces an element of statistical heterogeneity 
Table 4-Meta-analyses of Randomized Controlled Trials of SIT for Treating Allergic Rhinitis

\begin{tabular}{|c|c|c|c|c|c|}
\hline Study/Year & Patients & Allergens & $\begin{array}{l}\text { Symptom Scores, } \\
\text { SMD (95\% CI) }\end{array}$ & $\begin{array}{l}\text { Medication Scores, } \\
\text { SMD }(95 \% \mathrm{CI})\end{array}$ & Comment \\
\hline $\begin{array}{l}\text { Calderon } \\
\quad \text { et al }{ }^{43 / 2007}\end{array}$ & 2,871 adults & $\begin{array}{l}\text { SCIT } \\
\text { Seasonal }\end{array}$ & $\begin{array}{c}-0.73(-0.97,-0.50) \\
\mathrm{I}^{2}=63 \%\end{array}$ & $\begin{array}{c}-0.57(-0.82,-0.33) \\
\mathrm{I}^{2}=64 \%\end{array}$ & $\begin{array}{l}\text { No children included } \\
\text { No fatalities reported } \\
\text { Moderate heterogeneity }\end{array}$ \\
\hline $\begin{array}{l}\text { Radulovic } \\
\text { et } \mathrm{al}^{44} / 2010\end{array}$ & $\begin{array}{l}4,589 \text { adults and } \\
\text { children }\end{array}$ & $\begin{array}{l}\text { SLIT } \\
\text { Seasonal and } \\
\text { perennial }\end{array}$ & $\begin{array}{c}-0.49(-0.64,-0.34) \\
\mathrm{I}^{2}=81 \%\end{array}$ & $\begin{array}{c}-0.32(-0.43,0.21) \\
\mathrm{I}^{2}=50 \%\end{array}$ & $\begin{array}{l}\text { Considerable heterogeneity } \\
\text { despite inclusion of large trials }\end{array}$ \\
\hline $\begin{array}{l}\text { Penagos } \\
\quad \text { et al }{ }^{45 / 2006}\end{array}$ & 484 children & $\begin{array}{l}\text { SLIT } \\
\text { Seasonal and } \\
\text { perennial }\end{array}$ & $\begin{array}{c}-0.56(-1.01,-0.10) \\
\mathrm{I}^{2}=81 \%\end{array}$ & $\begin{array}{c}-0.76(-1.46,-0.06) \\
\mathrm{I}^{2}=86 \%\end{array}$ & Considerable heterogeneity \\
\hline $\begin{array}{l}\text { Olaguíbel and } \\
\text { Alvarez } \\
\text { Puebla }^{40 / 2005}\end{array}$ & 232 children & $\begin{array}{l}\text { SLIT } \\
\text { Seasonal and } \\
\text { perennial }\end{array}$ & $\begin{array}{c}-0.44(-1.22,-0.35) \\
\mathrm{I}^{2}=\text { Not reported }\end{array}$ & Not reported & $\begin{array}{l}\text { Small numbers } \\
\text { Heterogeneity not reported }\end{array}$ \\
\hline $\begin{array}{l}\text { Compalati } \\
\text { et } \mathrm{al}^{41} / 2009\end{array}$ & $\begin{array}{l}382 \text { adults } \\
\text { and children }\end{array}$ & $\begin{array}{l}\text { SLIT } \\
\text { House dust mite }\end{array}$ & $\begin{array}{c}-0.95(-1.77,-0.14) \\
\mathrm{I}^{2}=92 \%\end{array}$ & $\begin{array}{c}-1.88(-3.65,-0.12) \\
\mathrm{I}^{2}=95 \%\end{array}$ & $\begin{array}{l}\text { Considerable heterogeneity } \\
\text { despite focus on a single allergen }\end{array}$ \\
\hline $\begin{array}{l}\text { Di Bona } \\
\text { et al }{ }^{46} / 2010\end{array}$ & $\begin{array}{l}\text { 2,971 adults and } \\
\text { children with rhinitis }\end{array}$ & $\begin{array}{l}\text { SLIT } \\
\text { Grass pollen }\end{array}$ & $\begin{array}{c}-0.32(-0.44,-0.21) \\
\mathrm{I}^{2}=56 \%\end{array}$ & $\begin{array}{c}-0.33(-0.50,-0.16) \\
\mathrm{I}^{2}=78 \%\end{array}$ & Moderate heterogeneity \\
\hline
\end{tabular}

See Table 1 and 3 legends for expansion of other abbreviations. (Reproduced with permission from Calderón et al. ${ }^{42}$ )

into these meta-analyses. These limitations suggest a cautious interpretation of results when extending to all patient populations, allergens, and AR vs asthma. The complexity of using SIT and interpreting its efficacy is particularly evident with the concept of single vs multiallergen extract use. In the United States, allergists favor using multiallergen extracts, with the hope of addressing all major sensitivities, whereas allergists in Europe recommend against this practice, citing the rationale that inclusion of multiple allergens could potentially lead to a dilution effect, such that an effective dose is not given and also that proteolytic action of one extract on another might lead to its degradation. Although the aforementioned meta-analyses do include studies with multiallergen extracts, most of them used only single allergens. A recent analysis of multiallergen immunotherapy for $\mathrm{AR}$ and asthma looked at 13 studies (11 SCIT, one SLIT, one both) done over the past 50 years and concluded that SCIT using multiple unrelated allergens, particularly ones including ragweed or grass, is clinically effective, and also that similar conclusions are unable to be made for multiallergen SLIT due to insufficient data. ${ }^{81}$ Despite these differences, meaningful conclusions were able to be drawn from these analyses, with the consensus that allergen immunotherapy, administered either subcutaneously or sublingually, is effective for the treatment of AR and asthma.

\section{SAFETY AND HEALTH-CARE ECONOMICS OF ALLERGEN IMMUNOTHERAPY}

\section{Subcutaneous Immunotherapy}

It is generally accepted that a minimum of 3 years of SCIT is required to assess and note long-term efficacy, ${ }^{7}$ although it is not entirely clear if a longer duration would confer better and more sustained protection against the underlying allergic condition. ${ }^{82,83}$ The incidence of systemic reactions of SCIT ranges between $0.06 \%$ and $1.01 \%$ in those receiving injections, based on the most recent meta-analysis. Most reactions were considered mild, and death due to SCIT was rare (ie, incidence is about one per million to one per 2 million injections). ${ }^{36,84}$ As far as safety of SCIT in AR, the most recent Cochrane review found that epinephrine was administered in $0.13 \%$ of injections in the treated group compared with $0.01 \%$ in the placebo group, with no fatalities reported. Local reactions were common in the treated group compared with placebo (92\% vs $33 \%$ ), with the majority not requiring any additional treatment. ${ }^{43}$

To assess methods to improve safety, a study of 248 patients with persistent asthma were given omalizumab for 16 weeks as a pretreatment to patients undergoing specific immunotherapy to perennial aeroallergens (cat, dog, or house dust mite). With this approach, significantly fewer systemic allergic reactions occurred compared with placebo $(13.5 \%$ vs $26.2 \%$, $P=.017)$. More subjects taking omalizumab were able to achieve the target maintenance dose than placebo ( $87.3 \%$ vs $72.1 \%, P=.004) .85$ In another study with ragweed SIT, the combination of SIT and omalizumab improved severity scores associated with treatment and offered significant protection from severe IgE-mediated reactions during the impacted season. ${ }^{86}$ Similar results have been shown for pediatric patients with SAR and asthma receiving SIT for birch and grass. ${ }^{87}$

In contrast, there are limited data on pretreatment with montelukast for SCIT, and one study failed to demonstrate improved efficacy for SCIT despite a 
better-tolerated build-up phase. ${ }^{88}$ Prophylactic use of antihistamines has been shown to mitigate the frequency and severity of most reactions. As noted in the practice parameter, it is important to reiterate that unstable asthma is a contraindication to initiation of SCIT. A review of SIT pharmacoeconomics in the United States and the world by Lockey and Hankin ${ }^{89}$ concluded that SCIT is associated with substantial health-care cost savings by as much as $80 \%$ in one study observed at 3 years after discontinuing treatment. ${ }^{89,90}$

\section{Sublingual Immunotherapy}

Sublingual immunotherapy is generally well tolerated, with local side effects (perioral and oral itching or mild swelling) experienced in approximately threefourths of patients. To our knowledge, only six cases of anaphylaxis to SLIT have been reported thus far. ${ }^{7}$ In the most recent meta-analysis for SLIT in AR, no reported cases of severe systemic reaction or anaphylaxis were noted, and epinephrine use was not required for any of the systemic reactions. ${ }^{44}$ Unlike SCIT, there are insufficient data to determine an optimal duration for SLIT, although one study on grass pollen SLIT suggests that a 3-year course appears to confer sustained protection for at least 1 year after treatment. ${ }^{79}$ A health economics analysis of SLIT against pharmacotherapy has been performed for pollen and mite allergens and found SLIT to be cost-effective as well.91,92 Comparative analyses of SCIT vs SLIT for asthma and AR have been performed in at least four studies (three for pollen and one for house dust mites), and none of the studies showed any significant difference in the outcomes measured between the two approaches. ${ }^{93-96}$

\section{CONCLUSION AND Future Directions}

The prevalence of allergic respiratory disease continues to rise, and effective multimodal strategies are required to achieve optimal control of symptoms and prevent progression of the atopic condition. In a therapeutic field dominated by pharmacotherapy, allergen immunotherapy, with its disease-modifying traits and unique mechanisms of action, including the generation of Treg cells and induction of protective antibodies, may be an underused option that merits cautious consideration for the management of allergic respiratory diseases in the right patient. Despite the significant heterogeneity in study design, multiple meta-analyses have supported the efficacy and safety of SIT in allergic respiratory diseases. Given the varying degree of efficacy seen with each allergen and the possibility of systemic reaction or anaphylaxis, care must be exercised in selecting patients and prescribing allergenic extracts and ensuring the presence of trained support staff to manage any adverse reactions.

Avenues of research are being actively pursued to improve existing modalities as well as to develop other novel means of immunotherapy. As discussed, the use of anti-IgE therapy in conjunction with SCIT and SLIT has improved safety and tolerance of immunotherapy. Also of interest is the potential to use recombinant allergens that might provide better standardization of allergens and help tailor vaccines to individual patients. ${ }^{97}$ DNA vaccines that conjugate CpG motifs, bacterial cell-wall lipopolysaccharides, and other Th1 cell stimulants to allergens have been shown to facilitate immune deviation and dampen symptoms. ${ }^{98}$ Peptide immunotherapy using short linear T-cell epitopes of the antigen are also of interest, with the hope that such modalities would retain the antigen's immunogenicity while curtailing its allergenicity. ${ }^{99}$ Assessment of these approaches awaits ongoing trials. Allergic diseases have an immune basis to their origin and ongoing symptoms. Treatments that are directed toward the basis of these diseases hold, in our opinion, the possibility of mechanistic-driven treatment and more host disease-modifying outcomes.

\section{ACKNOWLEDGEMENTS}

Financial/nonfinancial disclosures: The authors have reported to CHEST that no potential conflicts of interest exist with any companies/organizations whose products or services may be discussed in this article.

\section{REFERENCES}

1. Ariano R, Canonica GW, Passalacqua G. Possible role of climate changes in variations in pollen seasons and allergic sensitizations during 27 years. Ann Allergy Asthma Immunol. 2010;104(3):215-222

2. Nathan RA. The burden of allergic rhinitis. Allergy Asthma Proc. 2007;28(1):3-9.

3. Bauchau V, Durham SR. Prevalence and rate of diagnosis of allergic rhinitis in Europe. Eur Respir J. 2004;24(5):758-764.

4. Sullivan PW, Ghuschyan VH, Slejko JF, Belozeroff V, Globe DR, Lin SL. The burden of adult asthma in the United States: evidence from the Medical Expenditure Panel Survey. J Allergy Clin Immunol. 2011;127(2): 363-369.

5. Weiss KB, Sullivan SD. The health economics of asthma and rhinitis. I. Assessing the economic impact. J Allergy Clin Immunol. 2001;107(1):3-8.

6. Akdis CA, Akdis M. Mechanisms of allergen-specific immunotherapy. J Allergy Clin Immunol. 2011;127(1):18-27.

7. Calderón MA, Casale TB, Togias A, Bousquet J, Durham SR, Demoly P. Allergen-specific immunotherapy for respiratory allergies: from meta-analysis to registration and beyond. J Allergy Clin Immunol. 2011;127(1):30-38.

8. Noon L. Prophylactic inoculation against hay fever. Lancet. 1911;177(4580):1572-1573.

9. Freeman J. Vaccination against hay fever: report of results during the first three years. Lancet. 1914;183(4730):1178-1180. 
10. Larché M, Akdis CA, Valenta R. Immunological mechanisms of allergen-specific immunotherapy. Nat Rev Immunol. 2006; 6(10):761-771.

11. Möller C, Dreborg S, Ferdousi HA, et al. Pollen immunotherapy reduces the development of asthma in children with seasonal rhinoconjunctivitis (the PAT-study). J Allergy Clin Immunol. 2002;109(2):251-256.

12. Pajno GB, Barberio G, De Luca F, Morabito L, Parmiani S. Prevention of new sensitizations in asthmatic children monosensitized to house dust mite by specific immunotherapy. A six-year follow-up study. Clin Exp Allergy. 2001;31(9): 1392-1397.

13. Bousquet J, Lockey R, Malling HJ. Allergen immunotherapy: therapeutic vaccines for allergic diseases. A WHO position paper. J Allergy Clin Immunol. 1998;102(4 pt 1):558-562.

14. Akkoc T, de Koning PJ, Rückert B, Barlan I, Akdis M, Akdis CA. Increased activation-induced cell death of high IFN-gammaproducing $\mathrm{T}(\mathrm{H}) 1$ cells as a mechanism of $\mathrm{T}(\mathrm{H}) 2$ predominance in atopic diseases. J Allergy Clin Immunol. 2008; 121(3):652-658.

15. Iliopoulos O, Proud D, Adkinson NF Jr, et al. Effects of immunotherapy on the early, late, and rechallenge nasal reaction to provocation with allergen: changes in inflammatory mediators and cells. J Allergy Clin Immunol. 1991;87(4):855-866.

16. Pienkowski MM, Norman PS, Lichtenstein LM. Suppression of late-phase skin reactions by immunotherapy with ragweed extract. J Allergy Clin Immunol. 1985;76(5):729-734.

17. Nanda A, O'connor M, Anand M, et al. Dose dependence and time course of the immunologic response to administration of standardized cat allergen extract. J Allergy Clin Immunol. 2004;114(6):1339-1344.

18. Arvidsson MB, Löwhagen O, Rak S. Allergen specific immunotherapy attenuates early and late phase reactions in lower airways of birch pollen asthmatic patients: a double blind placebo-controlled study. Allergy. 2004;59(1):74-80.

19. Warner JO, Price JF, Soothill JF, Hey EN. Controlled trial of hyposensitisation to Dermatophagoides pteronyssinus in children with asthma. Lancet. 1978;28;2(8096):912-915.

20. Durham SR, Ying S, Varney VA, et al. Grass pollen immunotherapy inhibits allergen-induced infiltration of CD4+ T lymphocytes and eosinophils in the nasal mucosa and increases the number of cells expressing messenger RNA for interferongamma. J Allergy Clin Immunol. 1996;97(6):1356-1365.

21. Varney VA, Hamid QA, Gaga M, et al. Influence of grass pollen immunotherapy on cellular infiltration and cytokine mRNA expression during allergen-induced late-phase cutaneous responses. J Clin Invest. 1993;92(2):644-651.

22. Van Ree R, Van Leeuwen WA, Dieges PH, et al. Measurement of IgE antibodies against purified grass pollen allergens (Lol p 1, 2, 3 and 5) during immunotherapy. Clin Exp Allergy. 1997;27(1):68-74.

23. Gleich GJ, Zimmermann EM, Henderson LL, Yunginger JW. Effect of immunotherapy on immunoglobulin E and immunoglobulin $\mathrm{G}$ antibodies to ragweed antigens: a six-year prospective study. J Allergy Clin Immunol. 1982;70(4):261-271.

24. Creticos PS, Van Metre TE, Mardiney MR, Rosenberg GL, Norman PS, Adkinson NF Jr. Dose response of IgE and IgG antibodies during ragweed immunotherapy. J Allergy Clin Immunol. 1984;73(1 pt 1):94-104.

25. Shamji MH, Durham SR. Mechanisms of immunotherapy to aeroallergens. Clin Exp Allergy. 2011;41(9):1235-1246.

26. Michils A, Ledent C, Mairesse M, Gossart B, Duchateau J. Wasp venom immunotherapy changes IgG antibody specificity. Clin Exp Allergy. 1997;27(9):1036-1042.

27. Francis JN, James LK, Paraskevopoulos G, Wong C, Calderon MA, Durham SR, Till SJ. Grass pollen immunotherapy: IL-10 induction and suppression of late responses precedes IgG4 inhibitory antibody activity. J Allergy Clin Immunol. 2008;121(5):1120-1125.

28. Müller UR, Helbling A, Bischof M. Predictive value of venom-specific IgE, IgG and IgG subclass antibodies in patients on immunotherapy with honey bee venom. Allergy. 1989;44(6):412-418.

29. Golden DB, Meyers DA, Kagey-Sobotka A, Valentine MD, Lichtenstein LM. Clinical relevance of the venom-specific immunoglobulin $\mathrm{G}$ antibody level during immunotherapy. J Allergy Clin Immunol. 1982;69(6):489-493.

30. Pilette C, Nouri-Aria KT, Jacobson MR, et al. Grass pollen immunotherapy induces an allergen-specific IgA2 antibody response associated with mucosal TGF-beta expression. J Immunol. 2007;178(7):4658-4666.

31. Francis JN, Till SJ, Durham SR. Induction of IL-10+CD4+ CD25+ T cells by grass pollen immunotherapy. J Allergy Clin Immunol. 2003;111(6):1255-1261.

32. Jutel M, Akdis M, Budak F, et al. IL-10 and TGF-beta cooperate in the regulatory $\mathrm{T}$ cell response to mucosal allergens in normal immunity and specific immunotherapy. Eur J Immunol. 2003;33(5):1205-1214.

33. Allam JP, Würtzen PA, Reinartz M et al. Phl p 5 resorption in human oral mucosa leads to dose-dependent and timedependent allergen binding by oral mucosal Langerhans cells, attenuates their maturation, and enhances their migratory and TGF-betal and IL-10-producing properties. I Allergy Clin Immunol. 2010;126(3):638-645.

34. Hamid QA, Schotman E, Jacobson MR, Walker SM, Durham SR. Increases in IL-12 messenger RNA+ cells accompany inhibition of allergen-induced late skin responses after successful grass pollen immunotherapy. J Allergy Clin Immunol. 1997;99(2):254-260.

35. Radulovic S, Jacobson MR, Durham SR, Nouri-Aria KT. Grass pollen immunotherapy induces Foxp3-expressing CD4+ CD25+ cells in the nasal mucosa. J Allergy Clin Immunol. 2008;121(6):1467-1472.

36. Cox LS, Nelson H, Lockey R, et al. Allergen immunotherapy: a practice parameter third update. J Allergy Clin Immunol. 2011;127(1 suppl):S1-S55.

37. Abramson MJ, Puy RM, Weiner JM. Injection allergen immunotherapy for asthma. Cochrane Database Syst Rev. 2010;4(8):CD001186.

38. Calamita Z, Saconato H, Pelá AB, Atallah AN. Efficacy of sublingual immunotherapy in asthma: systematic review of randomized-clinical trials using the Cochrane Collaboration method. Allergy. 2006;61(10):1162-1172.

39. Penagos M, Passalacqua G, Compalati E, et al. Metaanalysis of the efficacy of sublingual immunotherapy in the treatment of allergic asthma in pediatric patients, 3 to 18 years of age. Chest. 2008;133(3):599-609.

40. Olaguíbel JM, Alvarez Puebla MJ. Efficacy of sublingual allergen vaccination for respiratory allergy in children. Conclusions from one meta-analysis. J Investig Allergol Clin Immunol. 2005; 15(1):9-16.

41. Compalati E, Passalacqua G, Bonini M, Canonica GW. The efficacy of sublingual immunotherapy for house dust mites respiratory allergy: results of a GA2LEN meta-analysis. Allergy. 2009;64(11):1570-1579.

42. Calderón MA, Boyle RJ, Penagos M, Sheikh A. Immunotherapy: the meta-analyses. What have we learned? Immunol Allergy Clin North Am. 2011;31(2):159-173.

43. Calderon MA, Alves B, Jacobson M, Hurwitz B, Sheikh A, Durham S. Allergen injection immunotherapy for seasonal allergic rhinitis. Cochrane Database Syst Rev. 2007; (1):CD001936.

44. Radulovic S, Calderon MA, Wilson D, Durham S. Sublingual immunotherapy for allergic rhinitis. Cochrane Database Syst Rev. 2010; (12):CD002893. 
45. Penagos M, Compalati E, Tarantini F, et al. Efficacy of sublingual immunotherapy in the treatment of allergic rhinitis in pediatric patients 3 to 18 years of age: a meta-analysis of randomized, placebo-controlled, double-blind trials. Ann Allergy Asthma Immunol. 2006;97(2):141-148.

46. Di Bona D, Plaia A, Scafidi V, et al. Efficacy of sublingual immunotherapy with grass allergens for seasonal allergic rhinitis: a systematic review and meta-analysis. J Allergy Clin Immunol. 2010;126(3):558-566.

47. Ross RN, Nelson HS, Finegold I. Effectiveness of specific immunotherapy in the treatment of asthma: a meta-analysis of prospective, randomized, double-blind, placebo-controlled studies. Clin Ther. 2000;22(3):329-341.

48. Arvidsson MB, Löwhagen O, Rak S. Effect of 2-year placebocontrolled immunotherapy on airway symptoms and medication in patients with birch pollen allergy. J Allergy Clin Immunol. 2002;109(5):777-783.

49. García-Robaina JC, Sánchez I, de la Torre F, FernándezCaldas E, Casanovas M. Successful management of miteallergic asthma with modified extracts of Dermatophagoides pteronyssinus and Dermatophagoides farinae in a doubleblind, placebo-controlled study. J Allergy Clin Immunol. 2006;118(5):1026-1032.

50. Pifferi M, Baldini G, Marrazzini G, et al. Benefits of immunotherapy with a standardized Dermatophagoides pteronyssinus extract in asthmatic children: a three-year prospective study. Allergy. 2002;57(9):785-790.

51. Basomba A, Tabar AI, de Rojas DH, et al. Allergen vaccination with a liposome-encapsulated extract of Dermatophagoides pteronyssinus: a randomized, double-blind, placebo-controlled trial in asthmatic patients. J Allergy Clin Immunol. 2002; 109(6):943-948.

52. Roberts G, Hurley C, Turcanu V, Lack G. Grass pollen immunotherapy as an effective therapy for childhood seasonal allergic asthma. J Allergy Clin Immunol. 2006;117(2): 263-268.

53. Creticos PS, Reed CE, Norman PS, et al. Ragweed immunotherapy in adult asthma. N Engl J Med. 1996;334(8):501-506.

54. Adkinson NF Jr, Eggleston PA, Eney D, et al. A controlled trial of immunotherapy for asthma in allergic children. N Engl J Med. 1997;336(5):324-331.

55. Blumberga G, Groes L, Haugaard L, Dahl R. Steroid-sparing effect of subcutaneous SQ-standardised specific immunotherapy in moderate and severe house dust mite allergic asthmatics. Allergy. 2006;61(7):843-848.

56. Maestrelli P, Zanolla L, Pozzan M, Fabbri LM; Regione Veneto Study Group on the "Effect of immunotherapy in allergic asthma". Effect of specific immunotherapy added to pharmacologic treatment and allergen avoidance in asthmatic patients allergic to house dust mite. J Allergy Clin Immunol. 2004;113(4):643-649.

57. Jacobsen L, Niggemann B, Dreborg S, et al; (The PAT investigator group). Specific immunotherapy has long-term preventive effect of seasonal and perennial asthma: 10-year follow-up on the PAT study. Allergy. 2007;62(8):943-948.

58. Polosa R, Al-Delaimy WK, Russo C, Piccillo G, Sarvà M. Greater risk of incident asthma cases in adults with allergic rhinitis and effect of allergen immunotherapy: a retrospective cohort study. Respir Res. 2005;6:153.

59. Alvarez-Cuesta E, Berges-Gimeno P, González-Mancebo E, Fernández-Caldas E, Cuesta-Herranz J, Casanovas M. Sublingual immunotherapy with a standardized cat dander extract: evaluation of efficacy in a double blind placebo controlled study. Allergy. 2007;62(7):810-817.

60. Dahl R, Stender A, Rak S. Specific immunotherapy with SQ standardized grass allergen tablets in asthmatics with rhinoconjunctivitis. Allergy. 2006;61(2):185-190.
61. Pham-Thi N, Scheinmann P, Fadel R, Combebias A, Andre C. Assessment of sublingual immunotherapy efficacy in children with house dust mite-induced allergic asthma optimally controlled by pharmacologic treatment and mite-avoidance measures. Pediatr Allergy Immunol. 2007;18(1):47-57.

62. Novembre E, Galli E, Landi F, et al. Coseasonal sublingual immunotherapy reduces the development of asthma in children with allergic rhinoconjunctivitis. J Allergy Clin Immunol. 2004;114(4):851-857.

63. Marogna M, Tomassetti D, Bernasconi A, et al. Preventive effects of sublingual immunotherapy in childhood: an open randomized controlled study. Ann Allergy Asthma Immunol. 2008;101(2):206-211.

64. Bousquet J, Khaltaev N, Cruz AA, et al; World Health Organization; GA(2)LEN; AllerGen. Allergic Rhinitis and its Impact on Asthma (ARIA) 2008 update (in collaboration with the World Health Organization, GA(2)LEN and AllerGen). Allergy. 2008;63(suppl 86):8-160.

65. Soni A. Allergic Rhinitis: trends in use and expenditures, 2000 and 2005. Medical Expenditure Panel survey. AHRQ website. http://meps.ahrq.gov/mepsweb/data_files/publications/ st204/stat204.pdf Accessed December 18, 2011.

66. Hankin CS, Cox L, Lang D, et al. Allergen immunotherapy and health care cost benefits for children with allergic rhinitis: a large-scale, retrospective, matched cohort study. Ann Allergy Asthma Immunol. 2010;104(1):79-85.

67. Passalacqua G, Durham SR; Global Allergy and Asthma European Network. Allergic rhinitis and its impact on asthma update: allergen immunotherapy. J Allergy Clin Immunol. 2007;119(4):881-891.

68. Frew AJ, Powell RJ, Corrigan CJ, Durham SR; UK Immunotherapy Study Group. Efficacy and safety of specific immunotherapy with SQ allergen extract in treatment-resistant seasonal allergic rhinoconjunctivitis. J Allergy Clin Immunol. 2006;117(2):319-325.

69. Walker SM, Pajno GB, Lima MT, Wilson DR, Durham SR. Grass pollen immunotherapy for seasonal rhinitis and asthma: a randomized, controlled trial. J Allergy Clin Immunol. 2001;107(1):87-93.

70. Powell RJ, Frew AJ, Corrigan CJ, Durham SR. Effect of grass pollen immunotherapy with Alutard SQ on quality of life in seasonal allergic rhinoconjunctivitis. Allergy. 2007;62(11):1335-1338.

71. Durham SR, Walker SM, Varga EM, et al. Long-term clinical efficacy of grass-pollen immunotherapy. $N$ Engl J Med. 1999;341(7):468-475.

72. Eng PA, Borer-Reinhold M, Heijnen IA, Gnehm HP. Twelveyear follow-up after discontinuation of preseasonal grass pollen immunotherapy in childhood. Allergy. 2006;61(2):198-201.

73. Ewan PW, Alexander MM, Snape C, Ind PW, Agrell B, Dreborg S. Effective hyposensitization in allergic rhinitis using a potent partially purified extract of house dust mite. Clin Allergy. 1988;18(5):501-508

74. Varney VA, Edwards J, Tabbah K, Brewster H, Mavroleon G, Frew AJ. Clinical efficacy of specific immunotherapy to cat dander: a double-blind placebo-controlled trial. Clin Exp Allergy. 1997;27(8):860-867.

75. Des Roches A, Paradis L, Menardo JL, Bouges S, Daurés JP, Bousquet J. Immunotherapy with a standardized Dermatophagoides pteronyssinus extract. VI. Specific immunotherapy prevents the onset of new sensitizations in children. J Allergy Clin Immunol. 1997;99(4):450-453.

76. Inal A, Altintas DU, Yilmaz M, Karakoc GB, Kendirli SG, Sertdemir Y. Prevention of new sensitizations by specific immunotherapy in children with rhinitis and/or asthma monosensitized to house dust mite. J Investig Allergol Clin Immunol. 2007;17(2):85-91. 
77. Purello-D'Ambrosio F, Gangemi S, Merendino RA, et al. Prevention of new sensitizations in monosensitized subjects submitted to specific immunotherapy or not. A retrospective study. Clin Exp Allergy. 2001;31(8):1295-1302.

78. Matricardi PM, Kuna P, Panetta V, Wahn U, Narkus A. Subcutaneous immunotherapy and pharmacotherapy in seasonal allergic rhinitis: a comparison based on meta-analyses. J Allergy Clin Immunol. 2011;128(4):791-799.

79. Durham SR, Emminger W, Kapp A, Colombo G, de Monchy JG, Rak S, Scadding GK, Andersen JS, Riis B, Dahl R. Long-term clinical efficacy in grass pollen-induced rhinoconjunctivitis after treatment with SQ-standardized grass allergy immunotherapy tablet. J Allergy Clin Immunol. 2010;125(1):131-138.

80. Nelson HS, Oppenheimer J, Vatsia GA, Buchmeier A. A double-blind, placebo-controlled evaluation of sublingual immunotherapy with standardized cat extract. J Allergy Clin Immunol. 1993;92(2):229-236.

81. Nelson HS. Multiallergen immunotherapy for allergic rhinitis and asthma. J Allergy Clin Immunol. 2009;123(4):763-769.

82. Tabar AI, Arroabarren E, Echechipía S, García BE, Martin S, Alvarez-Puebla MJ. Three years of specific immunotherapy may be sufficient in house dust mite respiratory allergy. J Allergy Clin Immunol. 2011;127(1):57-63.

83. Cox L, Cohn JR. Duration of allergen immunotherapy in respiratory allergy: when is enough, enough? Ann Allergy Asthma Immunol. 2007;98(5):416-426.

84. Bernstein DI, Epstein T, Murphy-Berendts K, Liss GM. Surveillance of systemic reactions to subcutaneous immunotherapy injections: year 1 outcomes of the ACAAI and AAAAI collaborative study. Ann Allergy Asthma Immunol. 2010;104(6):530-535.

85. Massanari M, Nelson $H$, Casale $\mathrm{T}$, et al. Effect of pretreatment with omalizumab on the tolerability of specific immunotherapy in allergic asthma. J Allergy Clin Immunol. 2010;125(2):383-389.

86. Casale TB, Busse WW, Kline JN, et al; Immune Tolerance Network Group. Omalizumab pretreatment decreases acute reactions after rush immunotherapy for ragweed-induced seasonal allergic rhinitis. J Allergy Clin Immunol. 2006;117(1):134-140.

87. Kuehr J, Brauburger J, Zielen S, et al. Efficacy of combination treatment with anti-IgE plus specific immunotherapy in polysensitized children and adolescents with seasonal allergic rhinitis. J Allergy Clin Immunol. 2002;109(2):274-280.

88. Majak P, Rychlik B, Pułaski L, et al. Montelukast treatment may alter the early efficacy of immunotherapy in children with asthma. J Allergy Clin Immunol. 2010;125(6):1220-1227.
89. Lockey RF, Hankin CS. Health economics of allergen-specific immunotherapy in the United States. I Allergy Clin Immunol. 2011;127(1):39-43.

90. Ariano R, Berto P, Tracci D, Incorvaia C, Frati F. Pharmacoeconomics of allergen immunotherapy compared with symptomatic drug treatment in patients with allergic rhinitis and asthma. Allergy Asthma Proc. 2006;27(2):159-163.

91. Omnes LF, Bousquet J, Scheinmann P, et al. Pharmacoeconomic assessment of specific immunotherapy versus current symptomatic treatment for allergic rhinitis and asthma in France. Eur Ann Allergy Clin Immunol. 2007;39(5): 148-156.

92. Berto P, Passalacqua G, Crimi N, et al; Italian SPAI Study Group. Economic evaluation of sublingual immunotherapy vs symptomatic treatment in adults with pollen-induced respiratory allergy: the Sublingual Immunotherapy Pollen Allergy Italy (SPAI) study. Ann Allergy Asthma Immunol. 2006;97(5):615-621.

93. Mungan D, Misirligil Z, Gürbüz L. Comparison of the efficacy of subcutaneous and sublingual immunotherapy in mite-sensitive patients with rhinitis and asthma-a placebo controlled study. Ann Allergy Asthma Immunol. 1999; 82(5):485-490.

94. Khinchi MS, Poulsen LK, Carat F, André C, Hansen AB, Malling HJ. Clinical efficacy of sublingual and subcutaneous birch pollen allergen-specific immunotherapy: a randomized, placebo-controlled, double-blind, double-dummy study. Allergy. 2004;59(1):45-53.

95. Mauro M, Russello M, Incorvaia C, Gazzola GB, Di Cara G, Frati F. Comparison of efficacy, safety and immunologic effects of subcutaneous and sublingual immunotherapy in birch pollinosis: a randomized study. Eur Ann Allergy Clin Immunol. 2007;39(4):119-122.

96. Quirino T, Iemoli E, Siciliani E, Parmiani S, Milazzo F. Sublingual versus injective immunotherapy in grass pollen allergic patients: a double blind (double dummy) study. Clin Exp Allergy. 1996;26(11):1253-1261.

97. Pauli G, Larsen TH, Rak S, et al. Efficacy of recombinant birch pollen vaccine for the treatment of birch-allergic rhinoconjunctivitis. J Allergy Clin Immunol. 2008;122(5):951-960.

98. Tighe H, Takabayashi K, Schwartz D, et al. Conjugation of immunostimulatory DNA to the short ragweed allergen amb a 1 enhances its immunogenicity and reduces its allergenicity. J Allergy Clin Immunol. 2000;106(1 pt 1):124-134.

99. Moldaver D, Larché M. Immunotherapy with peptides. Allergy. 2011;66(6):784-791. 